\title{
Methylphenidate-Induced Raynaud's Phenomenon In Two Cases With Attention-Deficit/Hyperactivity Disorder
}

\section{Dikkat Eksikliği / Hiperaktivite Bozukluğu Olan İki Olguda Metilfenidat Kaynaklı Raynaud Fenomeni}

\author{
๑Hurşit Ferahkaya', ๑Ömer Faruk Akça' \\ 'Department of Child and Adolescent Psychiatry, Necmettin Erbakan University, Meram Faculty of Medicine, Konya, Turkey
}

\begin{abstract}
Attention - deficit / hyperactivity disorder is a common neurodevelopmental disorder in childhood, for which there are several different treatment options. Among the suggested medications, methylphenidate (a central nervous system stimulant) is the first option in the treatment of ADHD. Psychostimulants are associated with various vascular problems including peripheral vasculopathy. This report describes two patients with ADHD who developed Raynaud's phenomenon during the modified-release methylphenidate treatment.
\end{abstract}

Keywords: Methylphenidate, Raynaud's phenomenon, ADHD

\section{INTRODUCTION}

Attention - deficit / hyperactivity disorder (ADHD) is characterized by developmentally inappropriate symptoms of inattention, hyperactivity, and/or impulsivity. Stimulants such as methylphenidate (MPH) have been demonstrated in clinical trials to reduce inattention and hyperactivity in children with ADHD. ${ }^{[1]} \mathrm{MPH}$ acts by blocking dopamine (DA) and norepinephrine (NE) transporters, thereby preventing reuptake of these catecholamines by the neuron following their release into the synaptic gap. ${ }^{[2]}$ These drugs have been reported to be associated with several vascular diseases -that represent with necrotizing vasculitis- including secondary hypertension, cerebral vasculopathy, and erythema multiforme. ${ }^{[3,4]}$

Raynaud's phenomenon (RP) is a clinical syndrome characterized by recurrent episodes of vasospasm involving peripheral small vessels and is triggered by exposure to physical, chemical, or emotional stress. ${ }^{[5]}$ Patients complain

\begin{abstract}
Öz
Dikkat eksikliği / hiperaktivite bozukluğu, çocukluk çağında çok sayıda farklı tedavi seçeneği bulunan yaygın bir nörogelişimsel bozukluktur. Önerilen ilaçlar arasında metilfenidat (bir santral sinir sistemi stimülasyonu) DEHB tedavisinde ilk seçenektir. Psikostimülanlar, periferik vaskülopati dahil olmak üzere çeşitli vasküler problemlerle ilişkilidir. Bu raporda, modifiye salınımlı metilfenidat tedavisi sırasında Raynaud fenomeni geliştiren iki DEHB hastası sunulmaktadır.
\end{abstract}

Anahtar Kelimeler: Metilfenidat, Raynaud fenomeni, DEHB

of pain and feeling cold concurrent with sudden pallor and/ or cyanosis in their hands and/or feet. Females account for $60-90 \%$ of patients with this idiopathic condition. ${ }^{[6]}$ In this report, two cases of RP induced by a high dose of modifiedrelease methylphenidate treatment will be presented.

\section{CASES}

The first case is a 13-year-old boy who was admitted into our clinic with complaints of inattentiveness, untidiness, and low school success. Long-acting methylphenidate (OROS-MPH, Concerta $\left.{ }^{\circ}\right) 27 \mathrm{mg}$ was started based on a diagnosis of ADHD after completion of a psychiatric evaluation; four weeks later, the dosage was increased to $36 \mathrm{mg} /$ day due to partial response. Despite significant improvement in the ADHD symptoms, the treatment was stopped a month after because of a severe loss of appetite and weight. The patient was

Corresponding (illetişim): Hurşit Ferahkaya, Department of Child and Adolescent Psychiatry, Necmettin Erbakan University, Meram Faculty of Medicine, Konya, Turkey

E-mail (E-posta): drhursitferahkaya@gmail.com

Received (Geliş Tarihi): 07.12.2020 Accepted (Kabul Tarihi): 12.03.2021 
readmitted into our clinic two years later with similar complaints and was placed on a modified-release methylphenidate treatment (Medikinet $\odot$ retard) at a dosage of $20 \mathrm{mg} /$ day. At the next visit, the dosage was increased to $30 \mathrm{mg} /$ day; this led to a reduction in the ADHD symptoms of the patient. However, while there were no side effects with the $20 \mathrm{mg} /$ day dosage, the patient described feeling cold in both hands and feet which started one to two hours after each dose and lasted for seven to eight hours. The coldness in their hands was accompanied by paleness and then redness. The patient described no history of drug allergy or previous rheumatological disease. Considering the symptoms were similar to those of RP, the methylphenidate treatment was terminated and replaced with atomoxetine. There were no complaints of feeling cold in the hands and feet, nor appearance of redness with the treatment of atomoxetine.

The second case was a 16-year-old girl who was diagnosed with $A D H D$ at a different health center when she was 11 years old. At the time of diagnosis, she was placed on a treatment of longacting MPH $18 \mathrm{mg}$ (OROS-MPH, Concerta $\odot$ ) which lasted for only two months. She was admitted into our clinic with symptoms of inattentiveness, and a modified-release methylphenidate (Medikinet $\odot$ retard) treatment at a dosage of $10 \mathrm{mg} /$ day was started after psychiatric evaluation. The dosage was increased to 20 and $30 \mathrm{mg} /$ day at the next two visits, respectively. After the dosage was increased to $30 \mathrm{mg}$, she reported complaints of redness and cyanosis in her hands which began 20 to 30 minutes after drug intake. Her family and teacher also confirmed these symptoms. However, unlike the first case, she did not complain of feeling cold. These side effects were considered to be related to the Medikinet $\odot$ retard treatment since they were not seen in the weekend recesses. The patient described no history of drug allergy or previous rheumatological disease. Considering the symptoms were similar to those of RP, the methylphenidate treatment was terminated and no other treatment was administered. The redness and cyanosis on the hands disappeared after termination of the treatment.

\section{DISCUSSION}

$\mathrm{MPH}$ is the first-line pharmacological treatment for ADHD. ${ }^{[7]}$ $\mathrm{MPH}$ inhibits the dopamine and norepinephrine transporters in the neurons causing an increase in the extracellular dopamine and norepinephrine levels. Apart from its central effects, increased extracellular norepinephrine may cause vasoconstriction in the peripheral vascular system. ${ }^{[8]}$

$\mathrm{RP}$ is a peripheral vasculopathycharacterized by transientischemia in the hands and/or feet in response to cold or emotions. ${ }^{[9]}$ Several psychiatric drugs (including citalopram, dextroamphetamine, and $\mathrm{MPH}$ ) are associated with this phenomenon. ${ }^{[1,11]} \mathrm{RP}$ has been previously reported in child and adolescent patients on psychostimulant medications including short-acting, modifiedrelease, and OROS MPH, and dextroamphetamine. ${ }^{[11,13]}$ The authors of these reports stated that peripheral vasoconstriction may occur due to the dopaminergic and noradrenergic effect of the stimulants which may reflect clinically as RP. ${ }^{[11,13]}$ However, none of the previous reports declared a similarity or discrepancy among the forms of methylphenidate in terms of development of RP. In our cases, although RP did not occur during the use of OROS-MPH (Concerta $\odot$ ), there were signs of RP with the modified-release form of MPH (Medikinet $\odot$ retard). As far as we know, this report is the first to suggest that the vascular side effects of MPH may differ depending on the type of MPH used as indicated by these cases. Further studies are needed for comprehensive understanding of this condition.

\section{ETHICAL DECLARATIONS}

Informed Consent: Written informed consent was obtained from all participants who participated in this study.

Referee Evaluation Process: Externally peer-reviewed.

Conflict of Interest Statement: The authors have no conflicts of interest to declare.

Financial Disclosure: The authors declared that this study has received no financial support.

Author Contributions: All of the authors declare that they have all participated in the design, execution, and analysis of the paper, and that they have approved the final version

\section{REFERENCES}

1. Storebø OJ, Pedersen N, Ramstad E et al. Methylphenidate for attention deficit hyperactivity disorder (ADHD) in children and adolescents assessment of adverse events in non-randomised studies. Cochrane Database Syst Rev. 2018;2018(5).

2. Schiffer WK, Volkow ND, Fowler JS, Alexoff DL, Logan J, Dewey SL. Therapeutic doses of amphetamine or methylphenidate differentially increase synaptic and extracellular dopamine. Synapse. 2006;59(4):243-51.

3. Jefferson HJ, Jayne DR Peripheral vasculopathy and nephropathy in association with phentermine. Nephrol Dial Transplant. 1999;14(7):1761-3.

4. Cantu C, Arauz A, Murillo Bonilla LM, López M, Barinagarrementeria F. Stroke associated with sympathomimetics contained in over-the-counter cough and cold drugs. Stroke. 2003;34(7):1667-72.

5. Prete M, Fatone MC, Favoino E, Perosa F. Raynaud's phenomenon: From molecular pathogenesis to therapy. Autoimmun Rev [Internet]. 2014;13(6):655-67.

6. Jaffe I. Serotonin reuptake inhibitors in Raynaud's phenomenon. Lancet. 1995;345(8961):1378.

7. Golmirzaei J, Mahboobi H, Yazdanparast M, Mushtaq G, Kamal M, Hamzei E. Psychopharmacology of Attention-Deficit Hyperactivity Disorder: Effects and Side Effects. Curr Pharm Des. 2016;22(5):590-4.

8. Faraone S V. The pharmacology of amphetamine and methylphenidate: Relevance to the neurobiology of attention-deficit/hyperactivity disorder and other psychiatric comorbidities. Neurosci Biobehav Rev. 2018;87:255-70.

9. Wigley FM. Raynaud's phenomenon. N Engl J Med. 2002;347(13):1001-8.

10. Peiro AM, Margarit C TM. Citalopram-induced Raynaud's phenomenon. Rheumatol Int. 2007;27:599-601.

11. Syed RH, Moore TL. Methylphenidate and dextroamphetamine-induced peripheral vasculopathy. J Clin Rheumatol. 2008;14(1):30-3.

12. Bayram Ö, Hergüner S. OROS-methylphenidate-induced Raynaud's phenomenon: A dose-related side effect. J Child Adolesc Psychopharmacol. 2015;25(6):521-2.

13. Yu ZJ, Parker-Kotler C, Tran K, Weller RA, Weller EB. Peripheral vasculopathy associated with psychostimulant treatment in children with attentiondeficit/hyperactivity disorder. Curr Psychiatry Rep. 2010;12(2):111-5. 